\title{
ANNOTATED CHECKLIST OF CROATIAN RIFFLE BEETLES (INSECTA: COLEOPTERA: ELMIDAE)
}

\author{
Vlatka Mičetić Stanković ${ }^{1,3 *}$, Manfred A. Jäch ${ }^{2}$ \& Mladen Kučinić ${ }^{3}$ \\ ${ }^{1}$ Croatian Natural History Museum, Demetrova 1, Zagreb \\ ${ }^{2}$ Naturhistorisches Museum Wien, Burgring 7, A - 1010 Wien, Austria \\ ${ }^{3}$ Department of Biology, Faculty of Science, Rooseveltov trg 6, 10000 Zagreb, Croatia
}

Mičetić Stanković, V., Jäch, M.A. \& Kučinić, M.: Annotated checklist of Croatian riffle beetles (Insecta: Coleoptera: Elmidae). Nat. Croat., Vol. 24, No. 1, 93-109, 2015, Zagreb

In this paper an annotated checklist of Croatian riffle beetles is presented. It is a result of a literature review, revision of museum collections, implementation of results from various environmental impact and baseline studies, as well as field investigations throughout Croatia from 2002-2013. Altogether 23 species in eight genera of Elmidae were identified. Five species are new for the Croatian fauna: Elmis rioloides (Kuwert 1890), Esolus angustatus (Müller 1821), E. pygmaeus (Müller 1806), Oulimnius tuberculatus (Müller 1806) and Stenelmis consobrina Dufour 1835. Furthermore, the occurrence of Elmis aenea (Müller 1806) in Croatia is confirmed.

Keywords: Insecta, Coleoptera, Elmidae, riffle beetles, first records, freshwater, water beetles

Mičetić Stanković, V., Jäch, M.A. \& Kučinić, M.: Popis slapoljuba (Insecta: Coleoptera: Elmidae) Hrvatske s napomenama. Nat. Croat., Vol. 24, No. 1, 93-109, 2015, Zagreb

U ovom je radu dat popis slapoljuba Hrvatske s napomenama o njihovoj biologiji i staništima u Hrvatskoj. Rezultat je pregleda literature, uvida u muzejske zbirke, implementacije rezultata stručnih studija i elaborata, kao i prikupljanja vodenih kornjaša tijekom raznih terenskih istraživanja duž Hrvatske u razdoblju od 2002. do 2013. godine. Ukupno su utvrđene 23 vrste slapoljuba s pet novih vrsta za faunu Hrvatske: Elmis rioloides (Kuwert 1890), Esolus angustatus (Müller 1821), E. pygmaeus (Müller 1806), Oulimnius tuberculatus (Müller 1806) i Stenelmis consobrina Dufour 1835. Potvrđena je i prisutnost vrste Elmis aenea (Müller 1806) u Hrvatskoj.

Ključne riječi: Insecta, Coleoptera, Elmidae, slapoljub, prvi nalazi, slatkovodno, vodeni kornjaši

\section{INTRODUCTION}

Beetles are the largest order of insects, comprised of numerous representatives adapted to different environmental conditions. The ones that inhabit freshwater are known as water beetles, which is not a phylogenetic but an ecological term. Water beetles are connected with water in at least one stage of their life cycle (see also J̈̈̈н, 1998). Elmidae are considered as "true water beetles" (sensu Jäch, 1998). In Europe, Elmidae are represented by 10 genera and more than 40 species. In Croatia's neighbouring countries, where Elmidae have been systematically studied so far, 21 species were recorded from Austria, 16 from Hungary and 27 from Italy (J̈̈сн et al., 2006).

\footnotetext{
* corresponding author: vlatkams@hpm.hr
} 
Together with other water beetles, Elmidae are among the most common organisms in benthic communities of rivers and streams (MISERENDINO \& ARCHANGELSKY, 2006; JÄCH $\&$ BALKE, 2008). They have a complex life cycle which includes both water and riparian zones, and they are used as bioindicators for water quality and habitat preservation (see Crowson, 1981; Moog \& Jäch, 1995, 2003; Elliott, 2008; New, 2010).

Adult Elmidae are rather small-sized (on average $2-3 \mathrm{~mm}$ ) and at least partly covered with a hydrofuge pubescence that functions as a plastron and enables them direct intake of oxygen from the surrounding water (COOTER \& BARClay, 2006; KodAda et al., 2014).

Systematic research on the distribution of the family Elmidae in Croatia has not been carried out so far. Viktor Apfelbeck (1859-1934), insect dealer and curator in Sarajevo, was obviously the first entomologist who sampled Elmidae in Croatia. His specimens are deposited in various European museum collections.

One valid species of Elmidae, Esolus czwalinae Kuwert 1889, was even described from Croatia, as well as one species, which is currently regarded as a synonym (Lareynia croatica Kuwert $1890=$ Elmis obscura (Müller 1806)). Elmis rufiventris Kuwert 1890 (= Limnius intermedius Fairmaire 1881) and Riolus bosnicus Kuwert 1889 (= R. subviolaceus (Müller 1817)) were described from Croatia and Bosnia and Herzegovina (type locality not yet fixed).

In the second half of the twentieth century Novak $(1952,1970)$ collected water beetles in the Mediterranean part of Croatia where he identified seven species of Elmidae. Sporadically, Elmidae were investigated as part of benthic communities in projects with special interest in Croatia, i.e. National Park Plitvice Lakes (MatoničKin \& PAvletić, 1967; MatoničKin et al., 1971; Habdija et al., 1994), from where these authors identified five taxa: Esolus sp., Limnius sp., Riolus sp. and Elmis sp., and E. maugetii Latreille 1802. During investigations of benthic invertebrate communities in aquatic habitats in the Dinaric area, Marinković-Gospodnetić et al. (1980) highlighted that water beetles are unduly among the least investigated groups of aquatic insects in this region.

Additionally, today's awareness of the importance of biodiversity conservation challenges every country to list its flora and fauna, including groups with such small representatives like Elmidae. JäcH et al. (2005) indicated that, unfortunately, the protection of nature is still equalized with protection of vertebrates; in the last 50 years six species of Elmidae and Hydraenidae became extinct in Austria, receiving no or little attention.

\section{MATERIAL AND METHODS}

This list is a result of a literature review, revision of museum collections, implementation of results of environmental impact studies and baseline studies, and various field investigations. The following museum collections were examined:

AI: $\quad$ Hungarian Natural History Museum, Budapest, Hungary

AII: $\quad$ National Museum of Bosnia and Herzegovina, Sarajevo, Bosnia and Herzegovina (closed since 2012): Apfelbeck Collection

CNHM: Croatian Natural History Museum, Zagreb, Croatia: Igallffy Beetles Collection (IC), Novak Insects Collection (NC), Redenšek Beetles Collection (RC), Weingärtner Beetles Collection (WC)

NMW: Vienna Natural History Museum, Wien, Austria 
Tab.1. Geographical coordinates of family Elmidae findings in Croatia.

\begin{tabular}{|c|c|c|c|}
\hline Site name & Latitude & Longitude & $\begin{array}{c}\text { Altitude } \\
(\mathrm{m})\end{array}$ \\
\hline Butina River, spring area & $\mathrm{N} 43^{\circ} 10^{\prime} 34.20^{\prime \prime}$ & E $17^{\circ} 24^{\prime} 25.30^{\prime \prime}$ & 252 \\
\hline Cetina River, Glavaš spring & $\mathrm{N} 43^{\circ} 58^{\prime} 36.00^{\prime \prime}$ & E $16^{\circ} 25^{\prime} 48.00^{\prime \prime}$ & 385 \\
\hline Cetina River, Preočki Most & 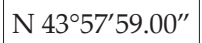 & E $16^{\circ} 25^{\prime} 53.00^{\prime \prime}$ & 370 \\
\hline Cetina River, Crveni Most & $\mathrm{N} 43^{\circ} 58^{\prime} 05.00^{\prime \prime}$ & E $16^{\circ} 25^{\prime} 53.00^{\prime \prime}$ & 365 \\
\hline Cetina River, Obrovac Sinjski & $\mathrm{N} 43^{\circ} 40^{\prime} 01.00^{\prime \prime}$ & E $16^{\circ} 41^{\prime} 04.00^{\prime \prime}$ & 300 \\
\hline Cetina River, Trilj & $\mathrm{N} 43^{\circ} 36^{\prime} 21.00^{\prime \prime}$ & E $16^{\circ} 43^{\prime} 46.00^{\prime \prime}$ & 295 \\
\hline Cetina River, Čikotina Lađa & $\mathrm{N} 43^{\circ} 31^{\prime} 59.00^{\prime \prime}$ & E $16^{\circ} 44^{\prime} 42.00^{\prime \prime}$ & 250 \\
\hline Cetina River, Radmanove Mlinice & $\mathrm{N} 43^{\circ} 26^{\prime} 16.00^{\prime \prime}$ & E $16^{\circ} 45^{\prime} 11.00^{\prime \prime}$ & 15 \\
\hline Dobra River, Bistrica spring & $\mathrm{N} 45^{\circ} 16^{\prime} 27.00^{\prime \prime}$ & E $15^{\circ} 17^{\prime} 28.00^{\prime \prime}$ & 245 \\
\hline Dobra River, spring near Podumol & $\mathrm{N} 45^{\circ} 21^{\prime} 27.30^{\prime \prime}$ & E $15^{\circ} 18^{\prime} 31.20^{\prime \prime}$ & 182 \\
\hline Dobra River, Ribnjak spring & $\mathrm{N} 45^{\circ} 20^{\prime} 86.00^{\prime \prime}$ & E $15^{\circ} 15^{\prime} 57.00^{\prime \prime}$ & 239 \\
\hline Dobra River, Gojak spring & $\mathrm{N} 45^{\circ} 17^{\prime} 51.20^{\prime \prime}$ & E $15^{\circ} 16^{\prime} 02.50^{\prime \prime}$ & 219 \\
\hline Dobra River, spring area of Gojačka Dobra & $\mathrm{N} 45^{\circ} 18^{\prime} 18.00^{\prime \prime}$ & E $15^{\circ} 16^{\prime} 68.00^{\prime \prime}$ & 223 \\
\hline Dobra River, sampling site by Bridge Lešće & $\mathrm{N} 45^{\circ} 22^{\prime} 24.56^{\prime \prime}$ & E $15^{\circ} 21^{\prime} 21.74^{\prime \prime}$ & 144 \\
\hline Drava River, HP Čakovec, left drainage ditch & N $46^{\circ} 18^{\prime} 44.97^{\prime \prime}$ & E $16^{\circ} 27^{\prime} 59.10^{\prime \prime}$ & 162 \\
\hline $\begin{array}{l}\text { Drava River, HP Čakovec, right drainage ditch, } 7.5 \mathrm{~km} \\
\text { upstream from wastewater outlet of Varaždin city }\end{array}$ & $\mathrm{N} 46^{\circ} 18^{\prime} 44.63^{\prime \prime}$ & E $16^{\circ} 22^{\prime} 04.36^{\prime \prime}$ & 167 \\
\hline $\begin{array}{l}\text { Drava River, HP Čakovec, drainage derivation canal } \\
\text { between engine room and mouth of watercourse Jezerčica }\end{array}$ & $\mathrm{N} 46^{\circ} 18^{\prime} 52.38^{\prime \prime}$ & E $16^{\circ} 31^{\prime} 04.30^{\prime \prime}$ & 155 \\
\hline $\begin{array}{l}\text { Drava River, HP Čakovec, biological minimum in } 2.5 \mathrm{~km} \\
\text { before connecting to the drainage derivation canal }\end{array}$ & $\mathrm{N} 46^{\circ} 19^{\prime} 07.79^{\prime \prime}$ & E $16^{\circ} 34^{\prime} 16.74^{\prime \prime}$ & 151 \\
\hline $\begin{array}{l}\text { Drava River, HP Čakovec, accumulation, before recreation } \\
\text { centre }\end{array}$ & $\mathrm{N} 46^{\circ} 19^{\prime} 08.83^{\prime \prime}$ & E $16^{\circ} 21^{\prime} 50.99^{\prime \prime}$ & 166 \\
\hline $\begin{array}{l}\text { Drava River, HP Dubrava, drainage derivation canal } \\
\text { between engine room and } 200 \mathrm{~m} \text { after mouth of drainage } \\
\text { watercourse }\end{array}$ & $\mathrm{N} 46^{\circ} 19^{\prime} 11.54^{\prime \prime}$ & E $16^{\circ} 45^{\prime} 12.91^{\prime \prime}$ & 133 \\
\hline Drava River, HP Dubrava, right drainage ditch & $\mathrm{N} 46^{\circ} 19^{\prime} 06.63^{\prime \prime}$ & E $16^{\circ} 42^{\prime} 44.09^{\prime \prime}$ & 139 \\
\hline Drava River, HP Dubrava left drainage ditch & $\mathrm{N} 46^{\circ} 19^{\prime} 41.62^{\prime \prime}$ & E $16^{\circ} 42^{\prime} 58.36^{\prime \prime}$ & 144 \\
\hline $\begin{array}{l}\text { Drava River, biological minimum (before mouth of Plitvice } \\
\text { Stream) }\end{array}$ & $\mathrm{N} 46^{\circ} 19^{\prime} 44.00^{\prime \prime}$ & E $16^{\circ} 44^{\prime} 36.19^{\prime \prime}$ & 138 \\
\hline Drava River, HP Varaždin, accumulation & $\mathrm{N} 46^{\circ} 22^{\prime} 53.00^{\prime \prime}$ & E $16^{\circ} 11^{\prime} 10.54^{\prime \prime}$ & 184 \\
\hline Drava River, HP Varaždin, drainage derivation ditch & $\mathrm{N} 46^{\circ} 20^{\prime} 47.70^{\prime \prime}$ & E $16^{\circ} 16^{\prime} 16.90^{\prime \prime}$ & 141 \\
\hline Jadro River, spring & $\mathrm{N} 43^{\circ} 32^{\prime} 30.30^{\prime \prime}$ & E $16^{\circ} 31^{\prime} 11.80^{\prime \prime}$ & 111 \\
\hline Kosovčica River, spring & $\mathrm{N} 43^{\circ} 56^{\prime} 28.00^{\prime \prime}$ & E $16^{\circ} 15^{\prime} 10.00^{\prime \prime}$ & 260 \\
\hline Krka NP, Skradinski Buk waterfall & $\mathrm{N} 43^{\circ} 48^{\prime} 11.26^{\prime \prime}$ & E $15^{\circ} 57^{\prime} 56.29^{\prime \prime}$ & 41 \\
\hline Krka NP, Roški Slap waterfall & $\mathrm{N} 43^{\circ} 54^{\prime} 20.00^{\prime \prime}$ & E $15^{\circ} 58^{\prime} 22.00^{\prime \prime}$ & 55 \\
\hline Ljuta River, spring area & $\mathrm{N} 42^{\circ} 32^{\prime} 11.00^{\prime \prime}$ & E $18^{\circ} 22^{\prime} 41.00^{\prime \prime}$ & 70 \\
\hline
\end{tabular}




\begin{tabular}{|c|c|c|c|}
\hline Matica River, Crni Vir & $\mathrm{N} 43^{\circ} 07^{\prime} 09.20^{\prime \prime}$ & E $17^{\circ} 28^{\prime} 56.90^{\prime \prime}$ & 24 \\
\hline Matica River, next to the bridge downstream Staševica & $\mathrm{N} 43^{\circ} 08^{\prime} 20.60^{\prime \prime}$ & E $17^{\circ} 25^{\prime} 46.10^{\prime \prime}$ & 22 \\
\hline Mirna River & $\mathrm{N} 45^{\circ} 22^{\prime} 43.30^{\prime \prime}$ & E $13^{\circ} 53^{\prime} 29.2^{\prime \prime}$ & 20 \\
\hline Norin River, Upper Reach in Vid & $\mathrm{N} 43^{\circ} 04^{\prime} 49.80^{\prime \prime}$ & E $17^{\circ} 37^{\prime} 4.30^{\prime \prime}$ & 162 \\
\hline Petrinjčica River & $\mathrm{N} 45^{\circ} 21^{\prime} 7.93^{\prime \prime}$ & E $16^{\circ} 16^{\prime} 57.57^{\prime \prime}$ & 148 \\
\hline Plitvice lakes NP, Korana River in Korana Village & $\mathrm{N} 44^{\circ} 55^{\prime} 33.00^{\prime \prime}$ & E $15^{\circ} 37^{\prime} 09.00^{\prime \prime}$ & 390 \\
\hline $\begin{array}{l}\text { Plitvice lakes NP, Plitvica Stream } 50 \mathrm{~m} \text { upstream big } \\
\text { waterfall }\end{array}$ & $\mathrm{N} 44^{\circ} 54^{\prime} 08.00^{\prime \prime}$ & E $15^{\circ} 36^{\prime} 27.00^{\prime \prime}$ & 555 \\
\hline $\begin{array}{l}\text { Plitvice lakes NP, Tufa barrier Novakovića Brod in the line } \\
\text { of barrage lakes }\end{array}$ & $\mathrm{N} 44^{\circ} 54^{\prime} 07.00^{\prime \prime}$ & E $15^{\circ} 36^{\prime} 38.00^{\prime \prime}$ & 500 \\
\hline $\begin{array}{l}\text { Plitvice lakes NP, Tufa barrier Kozjak-Milanovac in the line } \\
\text { of barrage lakes }\end{array}$ & $\mathrm{N} 44^{\circ} 53^{\prime} 39.00^{\prime \prime}$ & E $15^{\circ} 36^{\prime} 32.00^{\prime \prime}$ & 545 \\
\hline Plitvice lakes NP, Tufa barrier Labudovac & $\mathrm{N} 44^{\circ} 52^{\prime} 17.00^{\prime \prime}$ & E $15^{\circ} 35^{\prime} 59.00^{\prime \prime}$ & 630 \\
\hline Plitvice lakes NP, Lower Reach of Crna rijeka River & 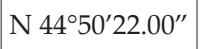 & E $15^{\circ} 35^{\prime} 59.00^{\prime \prime}$ & 665 \\
\hline Plitvice lakes NP, Middle Reach of Crna rijeka River & $\mathrm{N} 44^{\circ} 50^{\prime} 10.00^{\prime \prime}$ & E $15^{\circ} 36^{\prime} 30.00^{\prime \prime}$ & 670 \\
\hline Plitvice lakes NP, spring of Crna rijeka River & $\mathrm{N} 44^{\circ} 50^{\prime} 14.00^{\prime \prime}$ & E $15^{\circ} 36^{\prime} 28.00^{\prime \prime}$ & 680 \\
\hline Plitvice lakes NP, Upper Reach of Bijela rijeka River & $\mathrm{N} 44^{\circ} 50^{\prime} 04.00^{\prime \prime}$ & E $15^{\circ} 33^{\prime} 33.00^{\prime \prime}$ & 715 \\
\hline Plitvice lakes NP, spring of Bijela rijeka River & $\mathrm{N} 44^{\circ} 50^{\prime} 05.00^{\prime \prime}$ & E $15^{\circ} 33^{\prime} 43.00^{\prime \prime}$ & 720 \\
\hline Ruda River, spring & $\mathrm{N} 43^{\circ} 40^{\prime} 07.00^{\prime \prime}$ & E $16^{\circ} 47^{\prime} 56.00^{\prime \prime}$ & 320 \\
\hline Ruda River, $500 \mathrm{~m}$ downstream of spring & $\mathrm{N} 43^{\circ} 40^{\prime} 07.50^{\prime \prime}$ & E $16^{\circ} 47^{\prime} 49.20^{\prime \prime}$ & 330 \\
\hline Vitunjčica River & $\mathrm{N} 45^{\circ} 17^{\prime} 21.83^{\prime \prime}$ & E $15^{\circ} 09^{\prime} 25.63^{\prime \prime}$ & 340 \\
\hline Vojskova River & $\mathrm{N} 43^{\circ} 49^{\prime} 25.60^{\prime \prime}$ & E $16^{\circ} 37^{\prime} 54.60^{\prime \prime}$ & 570 \\
\hline Vrljika River, sampling site Opačac & N $43^{\circ} 27^{\prime} 15.90^{\prime \prime}$ & E $17^{\circ} 10^{\prime} 24.90^{\prime \prime}$ & 275 \\
\hline Vrljika River, sampling site Kamen most & $\mathrm{N} 43^{\circ} 25^{\prime} 52.80^{\prime \prime}$ & E $17^{\circ} 11^{\prime} 42.40^{\prime \prime}$ & 263 \\
\hline Vrljika River, sampling site downstream Runovići & $\mathrm{N} 43^{\circ} 23^{\prime} 12.70^{\prime \prime}$ & E $17^{\circ} 14^{\prime} 40.40^{\prime \prime}$ & 257 \\
\hline
\end{tabular}

Furthermore, in implemented environmental impact studies and baseline studies Elmidae were sampled as part of benthic invertebrate communities and afterwards identified by the authors of this article. Identification of Elmidae was conducted either on species level (Kerovec et al., 2007b; OiKon, 2014; GotTstein et al., 2009) or only on genus or family level (MraKovčić et al., 2010, 2011a-c, 2012, 2014; Kerovec et al., 2007a) when detailed identification was carried out subsequently. Also, riffle beetles were collected sporadically in various field investigations carried out throughout Croatia in 2002-2013. Sampling was conducted by Surber net, D net or benthos net, mesh size 300-500 $\mu \mathrm{m}$. Specimens were preserved in $80 \%$ ethanol in the field, and afterwards dry mounted. Only males were analysed since female genitalia are not always reliable as an identification feature. Identification was carried out using relevant literature (e.g. JäcH, 2006; Olmi, 1976, 1978; Berthélemy, 1979; Bertrand, 1954) and if needed, questionable specimens were compared with well-identified specimens housed in the World Water Beetle Collection \& Research Centre at the NMW. All riffle beetles collected during this study are deposited in the CNHM. Faunistic data published by OLMI (1976) were only partly 
considered, since information on the distribution of particular species is ambiguous and imprecise, often defined as "Balkan Peninsula" or "Yugoslavia".

Each record was georeferenced, using ArcGIS software if possible, and presented in Tab. 1. Classification and nomenclature of riffle beetles follow JäcH et al. (2006) and J̈̈сH et al. (in press).

\section{RESULTS}

This checklist includes 23 species in eight genera identified/recorded from Croatia. Five species are new for the Croatian fauna: Elmis rioloides (Kuwert 1890), Esolus angustatus (Müller 1821), E. pygmaeus (Müller 1806), Oulimnius tuberculatus (Müller 1806) and Stenelmis consobrina Dufour 1835. The occurrence of Elmis aenea (Müller 1806) in Croatia is confirmed. The occurrence of one species, Limnius muelleri (Erichson 1847), is very doubtful.

\section{Checklist of riffle beetles of Croatia}

( ${ }^{*}$ first record, ${ }^{* *}$ confirmed record)

Genus Elmis Latreille 1802

Elmis aenea (Müller 1806) **

Elmis bosnica (Zaitzev 1908)

Elmis latreillei Bedel 1878

Elmis maugetii Latreille 1802

Elmis obscura (Müller 1806)

Elmis rioloides (Kuwert 1890)*

Genus Esolus Mulsant \& Rey 1872

Esolus angustatus (Müller 1821) *

Esolus czwalinae Kuwert 1889

Esolus parallelepipedus (Müller 1806)

Esolus pygmaeus (Müller 1806) *

\section{Genus Limnius Illiger 1802}

Limnius intermedius Fairmaire 1881

[Limnius muelleri (Erichson 1847) *]

Limnius opacus (Müller 1806)

Limnius perrisi (Dufour 1843)

Limnius volckmari (Panzer 1793)

Genus Macronychus Müller 1806

Macronychus quadrituberculatus Müller 1806

Genus Oulimnius Gozis 1886

Oulimnius tuberculatus (Müller 1806) *

Genus Potamophilus Germar 1811

Potamophilus acuminatus (Fabricius 1792) 
Genus Riolus Mulsant \& Rey 1872

Riolus cupreus (Müller 1806)

Riolus nitens (Müller 1817)

Riolus subviolaceus (Müller 1817)

\section{Genus Stenelmis Dufour 1835}

Stenelmis canaliculata (Gyllenhal 1808)

Stenelmis consobrina Dufour 1835 *

\section{Additional data on the family Elmidae in Croatia}

\section{Elmis aenea (Müller 1806) **}

Biology: microphagous; in upper parts of streams, in lower altitude rivers in coexistence with E. rioloides and E. maugetii; on rocks and stones, on mosses or between macrophytes, in stronger water current (Berthélemy, 1966; Olmi, 1976; Hebauer, 1994; Jäch, 1994; ElliotT, 2008).

Habitats in Croatia: springs, spring areas, Upper, Middle and Lower reaches of large and small karstic Mediterranean rivers; tufa barriers; Upper and Lower reaches of large and small submountainous and mountainous karstic rivers in Dinaric Continental subecoregion; large rivers and channels in Pannonian lowlands on silicate bed; on submerged mosses, other macrophytes, between rocks, in slightly alkaline water, often in coexistence with E. rioloides.

\section{Distribution in Croatia}

Literature records: Vrana, Solin (NovaK, 1952); spring of Kosovčica River (Kerovec et al., 2007b); Cetina River: Crveni Most, Čikotina Lađa, Preočki Most and Radmanove Mlinice; Plitvice Lakes NP: Korana River in Korana Village, Tufa barrier Kozjak-Milanovac in the line of barrage lakes, Plitvica Stream $50 \mathrm{~m}$ upstream of big waterfall (MičETić Stanković, 2010).

Museum collection records: spring of Ombla River (AI); Knin (AII); Vrana, Solin, Split (IC); Solin, Vrana (NC).

New records: spring area of Butina River; Dobra River: Bistrica spring, Gojak spring, spring area of Gojačka Dobra, Ribnjak spring; Drava River: Hydropower plant Čakovec: left drainage ditch, right drainage ditch $7.5 \mathrm{~km}$ upstream of wastewater outlet of Varaždin city; Hydropower plant Dubrava: left drainage ditch, right drainage ditch, biological minimum (before Plitvica River confluence); Krka NP: Roški slap waterfall; Matica River: sampling site next to the bridge downstream of Staševica and Crni Vir; Norin River: Upper Reach in Vid; Ruda River: spring and $500 \mathrm{~m}$ downstream of spring; Vitunjčica River; Vojskova River; Vrljika River: sampling sites Opačac, Kamen most and downstream of Runovići.

\section{Elmis bosnica (Zaitzev 1908)}

Biology: no literature data.

Habitats in Croatia: springs, spring areas, Upper, Middle and Lower reaches of large and small karstic Mediterranean rivers; tufa barriers; springs, Upper and Middle reaches of mountainous and submountainous small karstic rivers in Dinaric Continental sube- 
coregion; on submerged mosses, other macrophytes, between pebbles, in slightly alkaline water, high or moderate water current.

\section{Distribution in Croatia}

Literature records: Croatia (J sites near Crveni Most, Obrovac Sinjski, Preočki Most and Trilj; Plitvice Lakes NP: spring and Upper Reach of Bijela rijeka River, spring, Middle Reach and Lower Reach of Crna rijeka River (MičEtić StANKović, 2010).

Museum collection records: Lastovo, Dalmacija (AI); Sinj, Makarska (NMW).

New records: spring of Jadro River; Krka NP: Skradinski Buk waterfall, Roški Slap waterfall; spring area of Ljuta River; Ruda River: spring and 500 m downstream of spring; Vojskova River.

\section{Elmis latreillei Bedel 1878}

Biology: microphagous; mainly in mountainous rivers and streams where it can be numerous, also very common in cold springs; underneath stones, between pebbles and gravel or on submerged mosses, between macrophytes, in low water current (BERTHÉLEmy, 1966; Olmi, 1976; Hebauer, 1994; Jäch, 1994; Elliott, 2008).

Habitats in Croatia: small lowland Pannonian rivers on carbonate bed; between pebbles and rocks.

\section{Distribution in Croatia}

Literature records: Croatia (OLmi, 1976; J̈̈сH et al., 2006).

Museum collection records: Gomirje, Lokve, Ludbreg (AI).

New records: Petrinjčica River.

\section{Elmis maugetii Latreille 1802}

Biology: microphagous; in hilly and mountainous rivers and streams, but also in lowland lotic habitats; on coarse substrates covered with mosses, between gravel, on submerged wood and macrophytes, exposed to high water velocity (OLMI, 1976; BERthÉLemy, 1966; Hebauer, 1994; Jäch, 1994; ElliotT, 2008).

Habitats in Croatia: small karstic Mediterranean rivers; Middle reaches of large lowland Pannonian rivers on carbonate bed; submountainous and mountainous Pannonian streams on silicate bed; between gravel.

\section{Distribution in Croatia}

Literature records: Imotski (PENECKe \& Müller, 1906); Bribirske Mostine, Imotski, Konavle Sinj, Solin, Vrana (NovaK, 1952); Croatia (Olmi, 1976; Jäch et al., 2006).

Museum collection records: Croatia, Gomirje, Ludbreg, Rijeka (AI); Knin, Split (AII); Sinj (IC); Bribirske Mostine, Imotski, Konavli, Orebić, Sinj, Solin, Vranjic, Vrana (NC); Lužnica, Podsused, Podsused Sava (RC); Podsused, Sljeme, Zagreb (WC).

New records: Vojskova River.

\section{Elmis obscura (Müller 1806)}

Biology: microphagous; usually wingless; both in lowland and mountainous lotic habitats; on stones and exposed roots of riparian vegetation, and on mosses (BERTHÉLEmy, 1966; Olmi, 1976; Hebauer, 1994; Jäch, 1994; Elliott, 2008).

Habitats in Croatia: lack of current data. 


\section{Distribution in Croatia}

Literature records: Croatia (J̈̈сH et al., 2006).

Museum collection records: Zagreb (AI, AII).

New records: none.

\section{Elmis rioloides (Kuwert 1890) *}

Biology: microphagous; in hilly and mountainous streams and rivers, it coexists on all altitudes with E. maugetii; on rocks, stones or mosses, between macrophytes (BERTHÉLEmy, 1966; Olmi, 1976; Hebauer, 1994; Jäch, 1994; Elliott, 2008).

Habitats in Croatia: springs, spring areas, Upper, Middle and Lower reaches of large and small karstic Mediterranean rivers; tufa barriers; Upper reaches of large and small submountainous and mountainous karstic rivers in Dinaric Continental subecoregion; large rivers and channels in Pannonian lowlands on silicate bed; on submerged mosses and other macrophytes, between rocks, in slightly alkaline water, often in coexistence with E. aenea.

\section{Distribution in Croatia}

Literature records: spring of Kosovčica River (Kerovec et al., 2007b); Cetina River: sampling sites near Crveni Most, Čikotina Lađa, Obrovac Sinjski, Preočki Most, Radmanove Mlinice and Trilj; Plitvice Lakes NP: Korana River in Korana Village, Tufa barrier KozjakMilanovac in the line of barrage lakes, Plitvica Stream $50 \mathrm{~m}$ upstream of big waterfall (MičEtić StAnKović, 2010).

Museum collection records: Zagreb (AI).

New records: Dobra River: Ribnjak spring, spring area of Gojačka Dobra; Drava River: Hydropower plant Dubrava: biological minimum (before mouth of Plitvice Stream), drainage canal between engine room and $200 \mathrm{~m}$ after mouth of drainage watercourse; Hydropower plant Čakovec: left drainage canal.

\section{Esolus angustatus (Müller 1821) *}

Biology: microphagous but also feeds on mosses; in mountain streams and rivers and cold springs; on gravel and pebbles covered with mosses, from moderate to low water current, often at higher altitudes than E. parallelepipedus and E. pygmaeus, often on silicate bed (Janssens, 1955; Berthélemy, 1966; Olmi, 1976; Hebauer, 1994; Jäch, 1994; Elliотт, 2008).

Habitats in Croatia: springs of small karstic rivers in Dinaric Continental subecoregion; submountainous and mountainous Pannonian streams on silicate bed; on mosses and other macrophytes, between pebbles.

\section{Distribution in Croatia}

Literature records: none.

Museum collection records: Dalmacija, Ludbreg, Zagreb (AI), Sljeme, Zagreb (WC).

New records: Dobra River: spring near Podumol, spring area of Gojačka Dobra.

\section{Esolus czwalinae Kuwert 1889}

Biology: microphagous; on mosses; poorly studied (Olmi, 1976).

Habitats in Croatia: described from "Croatia“(Kuwert, 1889); lack of current data. 
Distribution in Croatia

Literature records: Croatia (KuwerT, 1889).

Museum collection records: none.

New records: none.

\section{Esolus parallelepipedus (Müller 1806)}

Biology: lowland streams and large rivers; on gravel and coarse sand, from high to moderate flow with abundant filamentous algae (BERTHÉLEMY, 1966; HebAuer, 1994; Jäch, 1994; ElliotT, 2008).

Habitats in Croatia: Upper, Middle and Lower reaches of large karstic Mediterranean rivers; tufa barriers; springs, spring areas, Upper and Lower reaches of large and small submountainous and mountainous karstic rivers in Dinaric Continental subecoregion; large rivers and channels in Pannonian lowlands on silicate bed; on mosses and other macrophytes, between pebbles and gravel, in slightly alkaline water.

\section{Distribution in Croatia}

Literature records: Croatia (JÄCH et al., 2006); Cetina River: sampling sites near Crveni Most, Čikotina Lađa, Obrovac Sinjski, Preočki Most, Radmanove Mlinice and Trilj; Plitvice Lakes NP: spring and Upper Reach of Bijela rijeka River, Tufa barrier Labudovac, Korana River in Korana Village, Tufa barrier Kozjak-Milanovac in the line of barrage lakes, Tufa barrier Novakovića Brod in the line of barrage lakes, Plitvica Stream $50 \mathrm{~m}$ upstream of big waterfall (MičETić STANKOvić, 2010).

Museum collection records: Ludbreg, Maksimir, Pakrac, Zagreb (AI); Krk Island: stream near Baška, Fužine (NMW).

New records: Dobra River: spring near Podumol, spring area of Gojačka Dobra, Gojak spring, Bistrica spring; Drava River: Hydropower Cakovec: right drainage ditch in 7.5 $\mathrm{km}$ upstream of wastewater outlet of Varaždin city.

\section{Esolus pygmaeus (Müller 1806) *}

Biology: currently critically endangered or very rare; in large streams and rivers, springs; between rocks (BeRthélemy, 1966; JäCh, 1994; Elliott, 2008).

Habitats in Croatia: lack of current data.

Distribution in Croatia

Literature records: none.

Museum collection records: Lužnica (RC).

New records: none.

\section{Limnius intermedius Fairmaire 1881}

Biology: poorly known, similar habitats like L. volckmari, in small to moderately sized, rather warm streams; between rocks (BerthÉLemy, 1966; Olmi 1976; JÄCH, 1994; ElliotT, 2008).

Habitats in Croatia: lack of current data.

Distribution in Croatia

Literature records: Croatia (J̈̈̈H et al., 2006).

Museum collection records: Ludbreg, Pakrac, Zagreb (AI).

New records: none. 


\section{Limnius opacus (Müller 1806)}

Biology: microphagous; streams and rivers in hills and lower mountains, coexists with L. volckmari, between stones (BerthéLemy, 1966; Olmi, 1976; JäCH, 1994; Elliott, 2008).

Habitats in Croatia: lack of current data.

Distribution in Croatia

Literature records: Istra (OLMI, 1976); Croatia (J̈̈сH et al., 2006).

Museum collection records: none.

New records: none.

\section{Limnius perrisi (Dufour 1843)}

Biology: microphagous; in mountain streams, usually at higher altitudes than L. volckmari and L. opacus; on stones or between gravel and pebbles, in high water current (Berthélemy, 1966; Olmi, 1976; Hebauer, 1994; Jäch, 1994; Elliott, 2008).

Habitats in Croatia: springs of small mountainous karstic rivers in Dinaric Continental subecoregion; large rivers and channels in Pannonian lowlands on carbonate bed; between rocks and pebbles, on mosses.

\section{Distribution in Croatia}

Literature records: Croatia (J̈̈сH et al., 2006).

Museum collection records: Lokve (AI); Ludbreg (AII); Lužnica, Podsused Sava (RC).

New records: Dobra River: Ribnjak spring.

\section{Limnius volckmari (Panzer 1793)}

Biology: microphagous; in submountainous and lowland rivers and streams; between gravel, pebbles or on stones; from high to moderate flow with abundant filamentous algae, often on silicate bed (Janssens, 1955; Berthélemy, 1966; Olmi, 1976; Hebauer, 1994; Jä̈h, 1994; ElliotT, 2008).

Habitats in Croatia: springs, spring areas, Upper, Middle and Lower reaches of large and small karstic Mediterranean rivers; tufa barriers; springs, Upper and Middle reaches of large and small submountainous and mountainous karstic rivers in Dinaric Continental subecoregion; lowland karstic rivers in Dinaric Continental subecoregion; large rivers and channels in Pannonian lowlands on silicate bed; between gravel and pebbles, on rocks and stones, in slightly alkaline water.

\section{Distribution in Croatia}

Literature records: Imotski (Penecke \& Müller, 1906); Imotski, Konavle, Solin, Split, Žrnovnica (NovaK, 1952); Solin, Split (Olmi, 1976); Croatia (Jäch et al., 2006); Cetina River: Glavaš spring, sampling sites near Crveni most, Čikotina Lađa, Obrovac Sinjski, Preočki Most, Radmanove Mlinice and Trilj; Plitvice Lakes NP: Upper Reach of Bijela rijeka River, Middle Reach of Crna rijeka River, Korana River in Korana Village (MičEtić StAnković, 2010); Mirna River (OiкON, 2014).

Museum collection records: Ludbreg, Zagreb (AI); Knin, Ludbreg, Slavonija, Split (AII); Split (IC); Imotski, Konavle, Solin, Split, Zrnovnica, (NC); Lužnica (RC).

New records: Dobra River: Bistrica spring, spring area of Gojačka Dobra, spring near Podumol, Ribnjak spring, sampling site near Lešće Bridge; Vitunjčica River; Drava River: Hydropower plant Čakovec: drainage derivation canal between engine room and mou- 
th of watercourse Jezerčica; biological minimum in $2.5 \mathrm{~km}$ before connecting to the drainage derivation canal; accumulation, before recreation centre; Hydropower plant Dubrava: left drainage ditch; right drainage ditch; Hydropower plant Varaždin: accumulation and drainage derivation ditch; Ruda River: spring, and $500 \mathrm{~m}$ downstream of spring.

\section{Macronychus quadrituberculatus Müller 1806}

Biology: xylophagous; larvae and adults on submerged decaying wood in streams (Olmi, 1976; Hebauer, 1994).

Habitats in Croatia: large rivers and channels in Pannonian lowlands on carbonate bed.

Distribution in Croatia

Literature records: Sava River (Ćuk et al., 2014).

Museum collection records: Jaska (AI); Pakrac (AII); Zagreb (WC).

New records: none.

\section{Oulimnius tuberculatus (Müller 1806) *}

Biology: microphagous; in rivers both in lowlands and hills; on mosses and submerged wood, on leaves and stems of macrophytes or between fine gravel; avoids strong current (Berthélemy, 1966; Olmi, 1976; Hebauer, 1994; Jäch, 1994; Elliott, 2008).

Habitats in Croatia: Middle reaches and Lower reaches of large karstic Mediterranean rivers; tufa barriers; springs, Upper and Lower reaches of small karstic rivers in Dinaric Continental subecoregion; lowland karstic rivers in Dinaric Continental subecoregion; large rivers and channels in Pannonian lowlands on silicate bed; between pebbles or macrophytes, on fine gravel and sand.

\section{Distribution in Croatia}

Literature records: Cetina River: sampling site near Obrovac Sinjski; Plitvice Lakes NP: Korana River in Korana Village (MičEtić STAnković, 2010).

Museum collection records: Lokve, Maksimir, Pakrac (AI); Zagreb (AII).

New records: Dobra River: Bistrica spring, Gojak spring, spring near Podumol, sampling site near Lešće Bridge; Drava River: HP Cakovec: right drainage ditch in 7.5 km upstream of wastewater outlet of Varaždin city; Krka NP: Skradinski buk waterfall.

\section{Potamophilus acuminatus (Fabricius 1792)}

Biology: in potamal rivers; adults live on half submerged wood; today very rare (BERthÉlemy, 1966; Olmi, 1976; Hebauer, 1994; Jäch, 1994).

Habitats in Croatia: lack of current data.

\section{Distribution in Croatia}

Literature records: Istra (BERTOLINI, 1872), Croatia (JÄCH et al., 2006).

Museum collection records: Zagreb (AI).

New records: none.

\section{Riolus cupreus (Müller 1806)}

Biology: microphagous; in mountainous streams at lower altitudes, usually in calcareous water; between pebbles and gravel, or on stones from high to moderate or even slow water current (Janssens, 1955; Olmi, 1976; Berthélemy, 1966; Hebauer, 1994; Jäch, 1994; ElLiott, 2008). 
Habitats in Croatia: Upper, Middle and Lower reaches of large karstic Mediterranean rivers; tufa barriers; Upper, Middle and Lower reaches of large and small submountainous and mountainous karstic rivers in Dinaric Continental subecoregion; between pebbles and gravel, in slightly alkaline water.

\section{Distribution in Croatia}

Literature records: Croatia (J̈̈CH et al., 2006); Cetina River: sampling sites near Crveni Most, Čikotina Lađa, Obrovac Sinjski, Radmanove Mlinice and Trilj; Plitvice Lakes NP: Upper Reach of Bijela rijeka River, spring and Middle Reach of Crna rijeka River, Korana River in Korana Village, Tufa barrier Kozjak-Milanovac in the line of barrage lakes, Tufa barrier Labudovac, Tufa barrier Novakovića Brod in the line of barrage lakes, Plitvica Stream 50 m upstream of big waterfall (MičEтić STANкоvić, 2010).

Museum collection records: Ludbreg (AI); Lužnica (RC).

New record: Krka NP: Roški Slap waterfall.

\section{Riolus nitens (Müller 1817)}

Biology: poorly studied; often at lower altitudes than R. subviolaceus and R. cupreus; very common in the Mediterranean Region; in calcareous streams, mostly on substrates without vegetation (Berthélemy, 1966; Olmi, 1976; Jäch, 1994; Hebauer, 1994).

Habitats in Croatia: Upper and Lower reaches of large karstic Mediterranean rivers; tufa barriers; Upper reaches of large submountainous karstic rivers in Dinaric Continental subecoregion; lowland large karstic rivers in Dinaric Continental subecoregion; on mosses and other macrophytes, between gravel and pebbles, on stones, in slightly alkaline water, preferably in moderate water current.

\section{Distribution in Croatia}

Literature records: Omiš (NovaK, 1952); Croatia (J̈̈сH et al., 2006); Cetina River: sampling sites near Čikotina Lađa, Preočki Most and Radmanove Mlinice; Plitvice Lakes NP: Korana River in Korana Village, Tufa barrier Kozjak-Milanovac in the line of barrage lakes, Tufa barrier Novakovića Brod in the line of barrage lakes (MičEtić STANKović, 2010).

Museum collection records: Krk Island: stream near Baška (NMW).

New records: Krka NP: Skradinski Buk waterfall, Dobra River: sampling site near Lešće Bridge.

\section{Riolus subviolaceus (Müller 1817)}

Biology: microphagous; in hilly and mountainous streams, usually in calcareous water; between pebbles and gravel, or on mosses covering coarse substrate exposed to high and moderate water current (Janssens, 1955; Berthélemy, 1966; Olmi, 1976; Hebauer, 1994; JёсH, 1994; ElliotT, 2008).

Habitats in Croatia: Upper, Middle and Lower reaches of large karstic Mediterranean rivers; tufa barriers; springs, Upper and Middle reaches of small and large mountainous and submountainous karstic rivers in Dinaric Continental subecoregion; between pebbles and gravel, in slightly alkaline water.

\section{Distribution in Croatia}

Literature records: Konavle, Žrnovnica (NovaK, 1952); Croatia (Jäch et al., 2006); Cetina River: sampling sites near Crveni Most, Čikotina Lađa, Obrovac Sinjski, Radmanove 
Mlinice and Trilj; Plitvice Lakes NP: Upper Reach of Bijela rijeka River, spring and Middle Reach of Crna rijeka River, Korana River in Korana Village, Tufa barrier Kozjak-Milanovac in the line of barrage lakes, Tufa barrier Labudovac, Tufa barrier Novakovića Brod in the line of barrage lakes, Plitvica Stream $50 \mathrm{~m}$ upstream of big waterfall (MičETIĆ StANKović, 2010).

Museum collection records: Konavle, Žrnovnica (NC).

New record: Krka NP: Roški Slap waterfall.

\section{Stenelmis canaliculata (Gyllenhal 1808)}

Biology: rare species, larvae microphagous; on bottom of streams and rivers, or between stones and pebbles, on submerged and decaying wood at margins of lakes (Berthélemy, 1966; Olmi, 1976; Hebauer, 1994; Jäch, 1994).

Habitats in Croatia: spring areas of submountainous and mountainous small karstic rivers in Dinaric Continental subecoregion; rocks covered with mosses, pebbles covered with algae.

\section{Distribution in Croatia}

Literature records: Istra (BERTOLINI, 1872).

Museum collection records: none.

New records: Dobra River: spring area of Gojačka Dobra.

\section{Stenelmis consobrina Dufour 1835 *}

Biology: bottom of streams and rivers; on stones and pebbles or between these; at margins of lakes; currently extinct or critically endangered in most parts of Europe (BerthÉlemy, 1966; Olmi, 1976).

Habitats in Croatia: lack of current data.

\section{Distribution in Croatia}

Literature records: none.

Museum collection records: Zagreb (WC).

New records: none.

\section{DISCUSSION}

Although Croatia is a rather small country, it is very rich in surface running waters due to its geographical position and climatic characteristics (ŠAFAREK \& Šolić, 2011). Water beetles have not yet been investigated in the majority of the lotic habitats in Croatia, especially in the Pannonian ecoregion. Therefore, just like with other groups of insects, e.g. caddisflies or moth flies (Kučinić et al., 2013, 2014; KvifTe et al., 2013; Previšić et al., 2013), the number of water beetle species is expected to increase with future investigations. As for Elmidae, two additional taxa, Elmis syriaca zoufali (Kuwert 1890) and Stenelmis puberula Reitter 1887, are likely to be found in Croatia since both are known from Bosnia and Herzegovina. Otherwise the list of Elmidae seems quite complete. On the other hand, further DNA sequence studies might reveal even undescribed species, which are presently not recognizable on morphological characters.

Five new records of riffle beetles in Croatia is an expected result due to the previously poor knowledge of this water beetle family. Two new records, Esolus pygmaeus and 
Stenelmis consobrina, are represented only in the historical museum collections of Redenšek and Weingärtner, dating back to the first half of the twentieth century. Both species are nowadays regarded as critically endangered, very rare or extinct, and their presence in Croatia needs to be confirmed.

Esolus czwalinae was described from "Croatia" (without any further details). This species is also known from Bosnia and Herzegovina, France, Italy, Slovenia. The type material has not been retrieved so far.

Limnius muelleri has been recorded from Croatia (Imotski) by NovaK (1952). However, we were not able to retrieve this specimen. Furthermore, two specimens (one male, one female) from Ludbreg are deposited under this name in the collections of AII. Unfortunately, this museum is not accessible at present and we were thus not able to verify the identification by aedeagus examination. This species is likely to be confounded with $L$. intermedius.

The presence of Esolus angustatus in Croatia is here confirmed. The geographical distribution map published by Olmi (1976) is ambiguous and unclear, covering the whole Balkan Peninsula, without providing particular records.

New records for O. tuberculatus demonstrate its wide distribution in Croatia, from the Pannonian to the Mediterranean part.

Furthermore, new records of E. rioloides also demonstrate its wide distribution in Croatia. Olmi (1976) recorded this species from Bosnia and Herzegovina, but in the distribution map for this species some parts of Croatia are also marked. Interestingly, specimens of $E$. rioloides collected in various localities in Croatia differ from each other in both shape and structure of the pronotum. Specimens from Dobra River, Plitvice Lakes NP or spring of Kosovčica River have a pronotum "typical" for representatives of this species in Central Europe, with V-shaped ridges diverging anteriad. In specimens from Cetina River (locality Radmanove Mlinice) the pronotal ridges are found to be either V-shaped or U-shaped (as in E. aenea). It is well known that this species is very variable, but there are only few literature data about the difference in shape and structure of pronotum and elytra (e.g. by BERTHÉLEMY, 1979). Former identifications of Croatian species of Elmis, based only on external morphology, are to be regarded as doubtful. Revision of Novak's collection in CNHM showed that he did not examine genitalia. His work represents the only published data for E. aenea in Croatia (NovaK, 1952), in Dalmatia particularly; these records of E. aenea are herewith confirmed.

It is also necessary to point out that we did not include the record of E. maugetii from investigations in Plitvice Lakes NP, where Elmidae were analysed as part of the invertebrate benthic communities (MatoničKIn et al., 1971; HABDiJa et al., 1994), because identification was also based on external morphology only (Krulik, personal communication). In fact, during subsequent research of riffle beetles in this area (MičEtić STANкović, 2010) this species was not found.

In the future it will be important to focus on the biology of Riolus nitens and Elmis bosnica, since they have never been thoroughly studied (OLMI, 1976). Our results showed that both species usually inhabit calcareous rivers. In Europe, E. bosnica is distributed only in its south-eastern part. In Croatia, it is often the only Elmis species in springs and spring areas. Remarkably, E. latreillei, which is quite common in cold springs in Central Europe (JäCH, 1994; HebAUER, 1994), was not found in cold springs in Croatia during our study, which included more than 50 rivers and springs. We collected E. latreillei only in one lowland river, sampled at light during a warm summer night in June. 
In conclusion, some results of our study clearly corroborate the hypothesis of JäcH \& BALKE (2008) that detailed morphological and molecular analysis of the family Elmidae will increase the number of (unknown) species, especially in the Mediterranean part of Europe, a region with one of the highest speciation rates on a global scale (MitTERmeir et al., 1998; Myers et al., 2000).

\section{ACKNOWLEDGEMENTS}

The authors would like to thank all participants on various environmental impact studies and baseline studies which are cited in the article. Many thanks are due to Dr. Igor Stanković for collecting Elmidae in Dalmatia and Prof. Zlatko Mihaljević for collecting Elmidae in Krka NP. We also thank Dejan Kulijer and Mr. Dražen Kotrošan, National Museum of Bosnia and Herzegovina, Sarajevo, and Dr. György Makranczy and Dr. Gyõzõ Szél, Hungarian Natural History Museum, Budapest, for the loan of museum specimens. The study is a result of project 119-1193080-1206 (PL: M. Kučinić), supported by the Croatian Ministry of Science, Education and Sports.

Received April 28, 2015

\section{REFERENCES}

BerthÉLemy, C., 1966: Recherches écologiques et biogéographiques sur le Plécoptères et Coléoptères d'eau courante. Annales de Limnologie, 2(2), 227-458.

BERTHÉLEMY, C., 1979: Elmidae de la région paléarctique occidentale: systématique et répartition (Coleoptera Dryopoidea). Annales de Limnologie, 15(1), 1-104.

Bertolini, S., 1872: Catalogo sinonimico e topografico dei coleotteri d'Italia. Tipografia Cenniniana, Firenze, $263 \mathrm{pp}$.

Bertrand, H., 1954: Les Insectes aquatiques d'Europe. Volume 1. Collemboles, Hémiptères, Odonates, Plécoptères, Ephéméroptères, Mégaloptères, Planipennes, Coléoptères. Encyclopaedia Entomologique, Paris, 556 pp.

Cooter, J. \& Barclay, M.V.L., 2006: A Coleopterist's Handbook. The Amateur Entomologists' Society. $4^{\text {th }}$ edition, Kent, England, pp. 8-15.

Crowson, R.A., 1981: The biology of the Coleoptera. Academic Press, London, 802 pp.

ĆuK, R., Tomas, D. \& VučKović, I., 2014: Kakvoća rijeke Save u 2012. godini. Hrvatske vode, Časopis za vodno gospodarstvo, Zagreb, 22(88), 97-106.

ElLiotr, J.M., 2008: The ecology of riffle beetles (Coleoptera: Elmidae). Freshwater Biology, 1, 189-203.

Gottstein, S., ŽGAnec, K. \& Kerovec, M., 2009: Potencijalni utjecaj HE Lešće na zajednice makroskopskih vodenih beskralješnjaka izvorišnih područja gornjeg toka Gojačke Dobre. Prirodoslovno-matematički fakultet, Biološki odsjek, Zoologijski zavod, 125 pp.

Habdija, I., Primc HabdiJA, B. \& Belinić, I., 1994: Functional community organization of macroinvertebrates in lotic habitats of the Plitvice Lakes. Acta Hydrochimica et Hydrobiologica, 22(2), 85-92.

Hebauer, F., 1994: Entwurf eine Entomosoziologie aquatischer Coleoptera in Mitteleuropa (Insecta, Coleoptera, Hydradephaga, Hydrophiloidea, Drypoidea). Lauterbornia, 19, $43-57$.

JäCH, M.A., 1998: Annotated check list of aquatic and riparian/littoral beetle families of the world. In: J̈̈сн M.A. \& JI, L. (eds.): Water beetles of China, Zoologisch-Botanische Gesellschaft in Österreich and Wiener Coleopterologenverein, pp. 25-42.

Jäсн, M.A., 2006: Wasserkäfer. Skriptum zum Spezialpraktikum. Universität Wien, 426 pp.

J̈̈CH, M.A. \& BALKE, M., 2008: Global diversity of water beetles (Coleoptera) in freshwater. Hydrobiologia, $595,419-442$.

Jäch, M.A., Dietrich, F., \& RAunig, B., 2005: Rote Liste der Zwergwasserkäfer (Hydraenidae) und Krallenkäfer (Elmidae) Österreichs (Insecta: Coleoptera), pp. 211-284. In: ZuLKA, K.P. (ed.): Rote Listen gefährdeter Tiere Österreichs. Checklisten, Gefährdungsanalyse, Handlungsbedarf. Part 1: Säugetiere, Vögel, Heuschrecken, Wasserkäfer, Netzflügler, Schnabelfliegen, Tagfalter (Grüne Reihe des Le- 
bensministeriums, Vol. 14/1). Wien: Bundesministerium für Land- und Forstwirtschaft, Umwelt und Wirtschaft.

Jäch, M. A., Kodada, J. \& Čiampor, F. Jr., 2006: Elmidae, pp. 432-440. In: Löbl, I. \& A. Smetana (eds.): Catalogue of Palaearctic Coleoptera. Vol. 3. Apollo Books, Stenstrup, 690 pp.

Jäch, M.A., Kodada, J., Brojer, M., Shepard, W.D. \& ČIampor, F., 2015: World Catalogue of Elmidae Curtis, 1830 and Protelmidae Jeannel, 1950. Brill, Leiden (in press).

Janssens, E., 1955: Observation sur l'écologie de certains Elmidae. Bulletin et Annales de la Société Royale Belge d'Entomologie, 91, 11-12, 277-280.

Kerovec, M., Kučinić, M., Vuč́ović, I., Popijač, A., Mihaljević, Z., Previšić, A., Ivković, M., Gottstein, S., ZRINSKI, I. \& STANKović, I., 2007(a): Bioindikatorska i ekološka obilježja te rasprostranjenost i gustoća populacija faune tulara (Trichoptera, Insecta) duž toka rijeke Cetine. Stručna studija, Prirodoslovno-matematički fakultet, Zagreb, $158 \mathrm{pp}$.

Kerovec, M., Sipos, L., Plenković-Moraj, A., Mrakovčić, M., Ternjej, I., Mihaljević, Z., Hršak, V., Gottstein, S., Lajtner, J., Mustafić, P., Furač, L., Popijač, A., Žganec, K., Markić, M., Stanković, I., Mičetić, V., Slavikovski, A., Marčić, Z., Gligora, M., Kralj, K., Ignjatić-Zokić, T., Župan, M., Jurmanović, S., Turk, D., Jelenčić, M., Bartovsky, V., Vajdić, S. \& Plenković, L., 2007(b): Istraživanje utjecaja voda višestruko obogaćenih sulfatima na živu i neživu prirodu slivnog područja rijeke Krke. Prirodoslovno-matematički fakultet, Biološki odsjek, Zoologijski zavod, Zagreb, 97 pp.

KodAdA, J., Jäch, M.A. \& ČIAMPOR, F. JR., 2014: Ancyronyx reticulatus and A. pulcherrimus, two new riffle beetle species from Borneo, and discussion about elmid plastron structures (Coleoptera: Elmidae). Zootaxa 3760(3), 383-395.

Kučinić, M., Szivák, I., Pauls, S.U., BÁlint, M., Delić, A. \& VučKović, I., 2013: Chaetopteryx bucari sp. n., a new species from the Chaetopteryx rugulosa group from Croatia (Insecta, Trichoptera, Limnephilidae) with molecular, taxonomic and ecological notes on the group. ZooKeys, (1313-2989), 320, 1-28.

Kučinić, M., Previšić, A., Minoci, I., Ćuk, R., Delić, A., Žganec, K., Cerjanec, D. \& VučKović, I., 2014: The first finding of the Drusus bosnicus group (Insecta, Trichoptera, Limnephilidae) in Croatia with some notes on diversity, taxonomy, distribution and ecology of genus Drusus in Croatia and in Dinaric karst of the Balkan Peninsula. Natura Croatica, 23(2), 365-377.

KuwERT, A.F., 1889: General-Uebersicht der Riolus- und Esolus-Arten des europäischen- und Mittelmeerfaunengebiets. Societas entomologica 4(3), 24-26; 4(4), 32-33.

KuWERT, A.F., 1890: Bestimmungstabellen der Parniden Europas, der Mittelmeerfauna, sowie der angrenzenden Gebiete. Verhandlungen der Zoologisch-Botanischen Gesellschaft in Wien, 40, 15-54.

Kvifte, G.M., Ivković, M. \& Klarić, A., 2013: New records of moth flies (Diptera: Psychodidae) from Croatia, with the description of Berdeniella keroveci sp.nov. Zootaxa, 3737(1), 57-67.

Marinković-Gospodnetić, M., KReK, S., Tanasijević, M. \& KaĆAnski, D., 1980: Fauna vodenih insekata. (Fauna of the water Insects). Akademija nauka i umjetnosti BiH, special issue, Sarajevo, 47, 65-74.

MatoničKin, I. \& Pavletić, Z., 1967: Hidrologija potočnog sistema Plitvičkih jezera i njegove ekološkobiocenološke značajke. Krš Jugoslavije, JAZU, Zagreb, 5, 83-126.

MatoničKin, I., PAVletić, Z., TAVČAR, V. \& KRKAČ, N., 1971: Limnološka istraživanja reikotopa i fenomena protočne travertinizacije u Plitvičkim jezerima. Prirodoslovna istraživanja, Acta Biologica, 7(1), 1-88.

Mičetić Stanković, V., 2010: Vodeni kornjaši (Insecta: Coleoptera) u mikrostaništima krških izvora i tekućica. Doktorska disertacija, Zoologijski zavod, Biološki odsjek, Prirodoslovno-matematički fakultet Sveučilišta u Zagrebu, 250 pp.

Miserendino, M.L. \& Archangelsky, M., 2006: Aquatic Coleoptera Distribution and Environmental Relationships in a Large Patagonian River. International Review of Hydrobiology, 91(5), 423-437.

Mittermeier, R.A., Myers, N., Thomsen, J.B., DA Fonseca, G.A.B. \& Olivieri, S., 1998: Biodiversity hotspots and major tropical wilderness areas: Approaches to setting conservation priorities. Conservation Biology, 12, 516-520.

Moog, O. \& Jäch, M.A., 1995: Coleoptera (Käfer): Elmidae -Teil III A,B,C,D, 42 pp. In: Moog, O. (ed.) (1995): Fauna Aquatica Austriaca. Wasserwirtschaftskataster, Bundesministerium für Land- und Forstwirtschaft, Wien.

Moog, O. \& Jäсн, M.A., 2003: Coleoptera (Käfer): Elmidae. In: Moog, O. (ed.): Fauna Aquatica Austriaca, edition 2002. Wasserwirtschaftskataster, Bundesministerium für Land- und Forstwirtschaft, Umwelt und Wasserwirtschaft, Wien.

Mrakovčić, M., Mustafić, P., Mišetić, S., Plenković-Moraj, A., Mihaljević, Z., Kerovec, M., Zanella, D., Ćaleta, M., Buj, I., Marčić, Z., Kralj Borojević, K., Žutinić, P., 2010: Fizikalno-kemijske, biološke i ihtiološke značajke nadzemnih voda hidroenergetskog sustava HE Varaždin, HE Čakovec i HE Dubrava u 2009. godini (Physical, chemical, biological and ichthyological characteristics of waters of 
hydroelectric power systems HE Varaždin, HE Čakovec and HE Dubrava in year 2009). Elaborat, Prirodoslovno-matematički fakultet, Zagreb, 248 pp.

Mrakovčić, M., Mustafić, P., Mišetić, S., Plenković-Moraj, A., Mihaljević, Z., Kerovec, M., Zanella, D., Ćaleta, M., Buj, I., Marčić, Z., Kralj Borojević, K. \& Žutinić, P., 2011(a): Fizikalno-kemijske, biološke i ihtiološke značajke nadzemnih voda hidroenergetskog sustava HE Varaždin, HE Čakovec i HE Dubrava u 2010.godini (Physical, chemical, biological and ichthyological characteristics of waters of hydroelectric power systems HE Varaždin, HE Čakovec and HE Dubrava in year 2010). Elaborat, Prirodoslovno-matematički fakultet, Zagreb, 250 pp.

Mrakovčić, M., Mustafić, P., Mišetić, S., Plenković-Moraj, A., Mihaljević, Z., Kerovec, M., Zanella, D., Ćaleta, M., Marčić, Z., Buj, I., Gligora Udovič, M., Kralj Borojević, K. \& Žutinić, P., 2012: Fizikalno-kemijske, biološke i ihtiološke značajke nadzemnih voda hidroenergetskog sustava HE Varaždin, HE Čakovec i HE Dubrava u 2011. godini (Physical, chemical, biological and ichthyological characteristics of waters of hydroelectric power systems HE Varaždin, HE Čakovec and HE Dubrava in year 2011). Elaborat, Prirodoslovno-matematički fakultet, Zagreb, 421 pp.

Mrakovčić, M., Mustafić, P., Mišetić, S., Plenković-Moraj, A., Mihaljević, Z., Kerovec, M., Zanella, D., Ćaleta, M., Marčić, Z., Buj, I., Kralj Borojević, K., Gligora Udovič, M. \& Žutinić, P., 2014: Fizikalno-kemijske, biološke i ihtiološke značajke nadzemnih voda hidroenergetskog sustava HE Varaždin, HE Čakovec i HE Dubrava u 2013. godini (Physical, chemical, biological and ichthyological characteristics of waters of hydroelectric power systems HE Varaždin, HE Čakovec and HE Dubrava in year 2013). Elaborat, Prirodoslovno-matematički fakultet, Zagreb, 245 pp.

Mrakovčić, M., Mustafić, P., Plenković-Moraj, A., Ternjej, I., Krulik, I., Stančić, Z., Zanella, D., Ćaleta, M., Marčić, Z., Kralj Borojević, K., Gligora Udovič, M. \& Žutinić, P., 2011(b): Ispitivanje i praćenje voda za HE Gojak i HE Lešće u 2011. godini (Water testing and monitoring for HPP Gojak and HPP Lešće in 2011). Elaborat, Prirodoslovno-matematički fakultet, Zagreb, 120 pp.

Mrakovčić, M., Kerovec, M., Mihaljević, Z., Ternjej, I., Mustafić, P., Zanella, D., ĆAleta, M., Marčić, Z., Buj, I., BRigić, A. \& MininjAč, T., 2011(c): Ihtiološka istraživanja na rijeci Krki s ciljem očuvanja ihtiofaune rijeke. Elaborat, Prirodoslovno-matematički fakultet, Zagreb, 113 pp.

MüLleR, P.W.J., 1806: IV. Beschreibung der um Odenbach im Departement von Donnersberg beobachteten Schlammkäfer, Limnius Illig. Magazin für Insektenkunde, 5, 184-206.

Myers, N., Mittermeier, R.A., Mittermeier, C.G., da Fonseca, G.A.B. \& Kent, J., 2000: Biodiversity hotspots for conservation priorities. Nature, 403, 853-858.

New, T.R., 2010: Beetles in Conservation. Wiley-Blackwell, West Sussex, 237 pp.

Nilsson, A., 1996: Aquatic Insects of North Europe. A Taxonomic Handbook. Vol. 1. Apollo Books, Stenstrup, 274 pp.

NovaK, P., 1952: Kornjaši Jadranskog primorja (Coleoptera). Jugoslavenska akademija znanosti i umjetnosti, 522 pp.

NovaK, P., 1970: Rezultati istraživanja kornjaša našeg otočja. In: VARIčAK, T. (ed.) Prirodoslovna istraživanja, Acta Biologica VI, Jugoslavenska akademija, Zagreb, 75 pp.

OIKON, 2014: Restoration plan for the old riverbed Mirna - Biological and Ecological research and baseline documentation, Oikon d.o.o., 402 pp.

Olmi, M., 1976: Fauna d'Italia. Vol. XII. Coleoptera: Dryopidae, Elminthidae. Edizioni Calderini, Bologna, 272 pp.

Olmi, M., 1978: Driopidi, Elmintidi (Coleoptera Dryopidae, Elminthidae). Guide per il riconoscimento delle specie animali delle acque interne Italiane. Consiglio nazionale delle ricerche AQ/1/6, 71 pp.

Penecke, K.A. \& Müller, J., 1906: Koleopterologische Ergebnisse einer Sammelreise nach Dalmatien im Sommer 1905. Verhandlungen der Zoologisch-Botanischen Gesellschaft in Wien, 57, 1-19.

Previšić, A., Ivković, M., MilišA, M. \& Kerovec, M., 2013: Caddisfly (Insecta: Trichoptera) fauna of Papuk Nature Park, Croatia. Natura Croatica, 22(1), 1-13.

ŠAfAreK, G. \& Šolić, T., 2011: Rijeke Hrvatske. Veda d.o.o., Križevci, 326 pp. 